\title{
Biodegradation of Textile Dye by Using Achromobacter xylosoxidans GRIRKNM1 1 Isolated from Dye Polluted Site
}

\section{N. Manikandan, S. Surumbar Kuzhali and R. Kumuthakalavalli*}

*Department of Biology, Gandhigram Rural Institute, Gandhigram, Tamilnadu, India

\begin{abstract}
Synthetic dyes are widely used in textile, paper, food, cosmetic and pharmaceutical industries. The textile industry accounts for two thirds of the total dyestuff market. During dyeing process approximately $10-15 \%$ of the dyes used are released into the wastewater. In the present study Achromobacter xylosoxidans GRIRKNM11 isolated and sequenced from the textile dye effluent site was able to decolorize the turquoise blue dye $(100 \mathrm{mg} / \mathrm{L})$ within $48 \mathrm{~h}$ at $37^{\circ} \mathrm{C}$ and $\mathrm{pH} 7.0$. Decolorisation was assayed using spectrophotometery and products formed during degradation were characterized through FTIR spectra.
\end{abstract}

Keywords: Achromobacter xylosoxidans; RKNM11; FTIR; Turquoise blue dye

\section{Introduction}

Textile industry is one of the greatest generators of liquid effluent pollutants due to the high quantities of water used in the dyeing processes. There are more than $10^{5}$ kinds of commercially available dyes with over $7 \times 10^{5}$ tonnes of dyestuff produced annually and it is estimated that 2,80,000 tones of textile dyes are discharged from such industrial effluent every year worldwide [1]. Almost $10 \%$ of the total amount of dyes used is found in the wastewater disposed from such industries [2]. The effluents from these industries are complex, containing a wide variety of dye products such as dispersants, acids, bases, salts, detergents and oxidants. Discharge of these colored effluents into the rivers and lakes reduce dissolved oxygen concentration, thus creating anoxic conditions that are lethal to resident organisms [3]. Dyes present in textile wastewater cause not only aesthetic problems but also threat to public health [4]. Most of the liquid and solid effluents from textile industries are treated by physical and chemical methods such as flocculation, adsorption, filtration and oxidation. Most of the physical methods, however, simply accumulate and concentrate dyes and create solid wastes, and so the problem of disposal still exists and chemical approaches like using natural adsorbents for removal of heavy metal oxidation with either peroxide or ozone are some of the attractive solutions for metal remediation [5]. However biological processes provide an alternative to existing technologies since they are more costeffective, environment friendly, and do not produce large quantities of sludge [6]. Many microorganisms belonging to different taxonomic groups of bacteria, fungi, actinomycetes and algae have been reported for their ability to decolorize dyes [7].

\section{Materials and Methods}

\section{Screening of decolourization}

Soil samples from the textile dye effluent polluted sites were collected $(10 \% \mathrm{~W} / \mathrm{V})$. Microorganisms from these soil samples were isolated using the screening medium comprised of yeast extract 30 $\mathrm{g}$, Nacl $3.0 \mathrm{~g}$ and peptone $0.5 \mathrm{~g}$ in 1 litre of distilled water with $0.1 \mathrm{~g}$ of turquoise blue dye, inoculated and incubated at $37^{\circ} \mathrm{C}$ under static condition and the $\mathrm{pH}$ was adjusted to 7.0 for $48 \mathrm{hrs}$. The broth of the decolorised culture was then transferred to a fresh screening medium to screen strains that has colour removal ability. The screening procedures were conducted repeatedly with screening medium until an efficient decolorising culture appeared.
Later $0.1 \mathrm{ml}$ aliquot of the isolated culture was spread on a nutrient agar medium and incubated at $37^{\circ} \mathrm{C}$ for $48 \mathrm{~h}$. Colonies surrounded by decolorised zone were selected. Isolates were once again tested for their color removal ability in emulsified culture and promising isolate was selected and its stock culture was maintained for further studies [8].

\section{Identification}

Bacterial isolate with the higher decolorisation efficiency was first identified by biochemical methods and further identification was performed through rDNA sequencing.

\section{Decolorization experiments}

In order to examine decolorisation potential of the isolated bacterial strain [9], the screening medium was added with $100 \mathrm{mg} / \mathrm{l}$ of turquoise blue dye inoculated with $5 \% \mathrm{~V} / \mathrm{V}$ of $24 \mathrm{~h}$ old bacterial culture $\left(1.2 \mathrm{X} 10^{5}\right)$; the $\mathrm{pH}$ was adjusted to 7 incubated at $37^{\circ} \mathrm{C}$ and for $48 \mathrm{~h}$. The aliquots $(3 \mathrm{ml})$ of culture media were withdrawn at different time intervals, centrifuged at $8000 \mathrm{rpm}$ for $10 \mathrm{~min}$. Decolorisation was monitored by measuring the absorbance of culture supernatant at 583 nm using UV spectrophotometer.

The decolorization activity was expressed in terms of the percentage decolorization:

Decolorization activity $(\%)=\frac{[A]-[B]}{[A]} \times 100$

[A]-Initial absorbance

[B]- Final absorbance

\section{Optimization}

To study the optimisation of temperature, $\mathrm{pH}$ and concentration

*Corresponding author: R. Kumuthakalavalli, Professor, Department of Biology, Gandhigram Rural Institute, Gandhigram, Dindigul-624302, Tamilnadu-624 302, India, E-mail: rkvgri@gmail.com

Received July 16, 2012; Accepted November 22, 2012; Published November 24, 2012

Citation: Manikandan N, Kuzhali SS, Kumuthakalavalli R (2012) Biodegradation of Textile Dye by Using Achromobacter xylosoxidans GRIRKNM11 Isolated from Dye Polluted Site. J Environ Anal Toxicol 2:160. doi:10.4172/2161-0525.1000160

Copyright: (C) 2012 Manikandan N, et al. This is an open-access article distributed under the terms of the Creative Commons Attribution License, which permits unrestricted use, distribution, and reproduction in any medium, provided the original author and source are credited. 
of dye on decolorisation in static condition, the nutrient medium was added with $100 \mathrm{mg}$ of dye inoculated with $5 \mathrm{ml}$ of $24 \mathrm{~h}$ old bacterial culture and incubated at different temperatures such as $28^{\circ} \mathrm{C}, 30^{\circ} \mathrm{C}$, $37^{\circ} \mathrm{C}, 40^{\circ} \mathrm{C}$ and $45^{\circ} \mathrm{C}$ at different $\mathrm{pH}$ such as $5,7,9$ and inoculated with the bacterial strain as discussed earlier. Percentage of decolourisation at different concentration of dye such as $100,500,1000 \mathrm{mg} / \mathrm{l}$ was measured at different time intervals $(12 \mathrm{~h})$ for $48 \mathrm{~h}$ as discussed earlier. All experiments were performed in three sets along with control without the bacterial strain [10].

\section{Heavy metal analysis}

After $48 \mathrm{~h}$ of incubation, $2 \mathrm{ml}$ of treated dye effluent was taken in a boiling tube and was digested using $10 \mathrm{ml}$ of triple acid solution $\left(\mathrm{HNO}_{3}, \mathrm{H}_{2} \mathrm{SO}_{4}\right.$ and $\mathrm{HCIO}_{4}$ in 9:2:1 proportion respectively) till the effluent becomes colorless [11]. The digested sample was filtered using whatmann number 1 filter paper for two times made upto $50 \mathrm{ml}$ and subjected for heavy metal assay using Atomic Absorption Spectroscopy. By comparing the performance of with the treatment, the results were analyzed.

\section{Infrared spectrum analysis}

The control (non degraded dye) and treated samples (degraded) were dried, mixed with $\mathrm{KBr}$ (1:20:0.02 $\mathrm{g}$ of sample with $\mathrm{KBr}$ at a final weight of $0.4 \mathrm{~g}$ ) [12]. The samples were then ground, desorbed at $65^{\circ} \mathrm{C}$ for $20 \mathrm{~h}$ and pressed to obtain IR-transparent pellets. The absorbance FT-IR spectrum analysis was done through Perkin -Elmer spectrometer. The spectra were collected within the range of 400 to 4000 $\mathrm{cm}^{-1}$. The FT-IR was first calibrated for background signal scanning with a control sample of pure $\mathrm{KBr}$, and then the experimental samples were scanned. The FT-IR spectrum of the control was subtracted from the spectra of the non-degraded and degraded dyes.

\section{Results and Discussion}

\section{Microorganism isolation and culture conditions}

Based on the screening experiment for decolorising turquoise blue dye, five bacterial strains namely A1, A2, A3, A4 and A5 were isolated from polluted soil and A4 strain showed maximum clear zone plate and sub cultured in liquid medium under static condition. Environmental biotechnology relies upon the pollutant degrading capacities of naturally occurring microbial consortium in which bacteria plays a central role Liu and Stolz $[13,14]$. Bacterial flora of the dye contaminated soil was dominated with Pseudomonas sp.,(30.0\%) followed by Bacillus sp.,(23.3\%), Achromobacter sp.,(13.3\%) and Micrococcus sp (13.3\%) and Actinomycetes(20.0\%). stated that decolorisation of acid orange was $90 \%$ within 24 hrs under static condition by using Pseudomonas $s p$. [10]. Under static condition electrons are available to azoreductase from NADH to decolorize azo dye.

\section{Strain identification and characterization}

Microscopic observation of the A4 strain cells exhibited G-ve rodshaped cells. On biochemical investigations this strain showed aerobic, motile, oxidase and catalase +ve, non lactose fermentation. Molecular studies revealed its characerisation as $16 \mathrm{~S}$ rDNA amplification has 1414 bp nucleotides in length identified as Achromobacter xylosoxidans and this $16 \mathrm{~S}$ rDNA nucleotide sequence has been deposited in Genbank and assigned accession number JN 624743 (Achromobacter xylosoxidans GRIRKNM11).

Comparison of $16 \mathrm{~S}$ rDNA sequences with sequences deposited in NCBI showed that isolate strain was most closely related to a cultured bacterium Achromobacter sp. clone F3feb50.16S ribosomal RNA gene partial sequence shown sequence similarity of $99 \%$. The phylogenetic tree showed the grouping of Achromobacter sp. (Figure 1).

\section{Decolorization experiments}

The decolorization potential of Achromobacter xylosoxidans in nutrient broth medium at different time intervals $12,24,36$ and $48 \mathrm{~h}$ was studied. The selected bacterial isolate was found to be potential enough to decolorize the dye. The effect of decolorisation was increased with increase in time. The decolorization rate of Achromobacter xylosoxidans in $48 \mathrm{~h}$ was maximum (i.e) $61.24 \pm 0.45 \%$ (Figure 2).

\section{Optimization of dye decolorization at different temperature, $\mathrm{pH}$ and concentration}

The decolorization efficiency of Achromobacter xylosoxidans at different temperature, $\mathrm{pH}$ and concentration of dye was studied. There was as increasing trend of decolorization with increase of time and temperature. However there was a decreasing trend from $38^{\circ} \mathrm{C}$ to $45^{\circ} \mathrm{C}$ (Figure 3). The decolorization rate of Achromobacter xylosoxidans at 48 $\mathrm{h}$ and at $37^{\circ} \mathrm{C}$ was maximum i.e $58.57+0.47 \%$.

The optimum temperature for Achromobacter xylosoxidans for

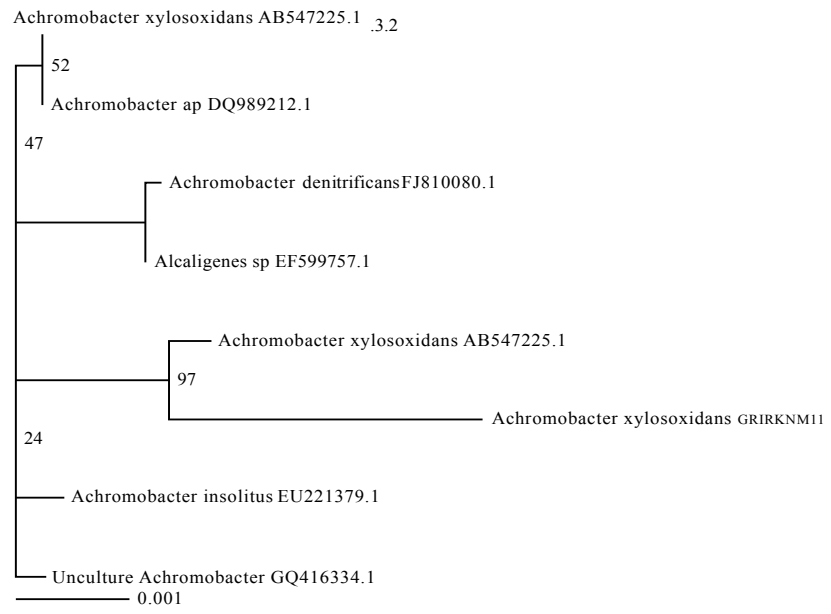

Figure 1: Phylogenetic tree of Achromobacter xylosoxidans for the partia sequenced based on $16 \mathrm{~S}$ Rdna.

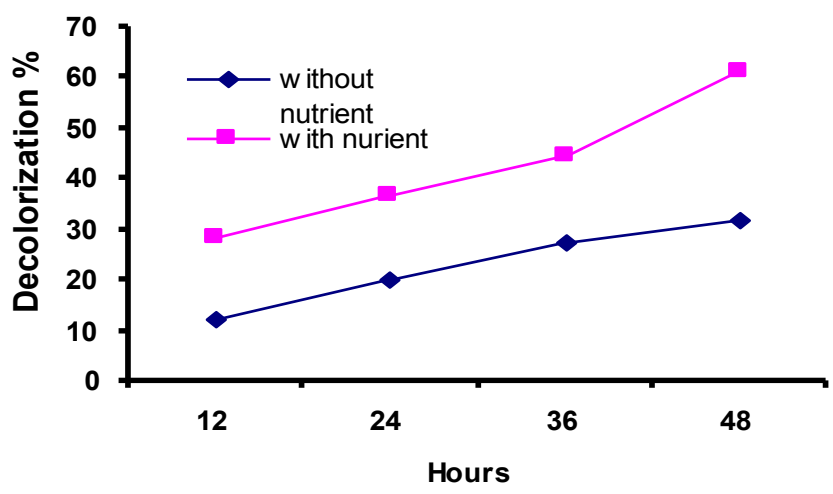

Figure 2: Decolorization of turquoise blue at different time intervals with Achromobacter xylosoxidans. 
maximum decolorisation was recorded as $37^{\circ} \mathrm{C}$. The decolorization activity of the culture was found to increase with increase in incubation temperature from $25^{\circ}$ to $37^{\circ} \mathrm{C}$ with maximum activity attained at $37^{\circ} \mathrm{C}$. Further increase in temperature above $40^{\circ} \mathrm{C}$ resulted in marginal decrease in decolorization activity. Similar observation was reported for the degradation of Disperse Blue 79 and Acid Orange 10 by Bacillus fusiformis KMK5 [15]. Decline in decolorization activity at higher temperature can be attributed to the loss of viability or to the denaturation of the azoreductase enzyme [16].

The decolorisation percentage of Achromobacter xylosoxidans in nutrient broth medium with different $\mathrm{pH} \mathrm{5,7}$ and 9 at different time intervals $12,24,36$ and $48 \mathrm{~h}$ was studied. $\mathrm{pH}$ of the medium has influenced the rate of decolorisation. There is an increasing rate of decolorisation from $\mathrm{pH} 5$ to $\mathrm{pH} 7$. At $\mathrm{pH} 7.0$ the decolorization rate of Achromobacter xylosoxidans during $48 \mathrm{~h}$ incubation was maximum (i.e) $56.32 \pm 0.47$ (Figure 4). Decolorisation efficiency was high at $\mathrm{pH}$ range of 7-9 by using Pesudomonas aeruoginosa NCIM 102.Majority of the azo dye reducing bacterial species reported dye reducing $\mathrm{pH}$ as 7 [17].

The decolorisation percentage of Achromobacter xylosoxidans in nutrient broth medium with different dye concentration viz 100 $\mathrm{mg}, 500 \mathrm{mg}$, and $1000 \mathrm{mg}$ at different time intervals 24,48 , and 72 $\mathrm{h}$ was studied. Concentration of dye strongly affected decolorisation rate; at increasing concentration rate of decolorisation was decreased. The decolorization rate of Achromobacter xylosoxidans at $48 \mathrm{~h}$ was maximum at $100 \mathrm{mg}$ (i.e) $58.57 \pm 0.47$ (Figure 5).

\section{Removal of heavy metal from dye}

Analysis of heavy metals of the dye isolation before and after biological treatment was assessed. In this study Achromobacter xylosoxidans showed the broad spectrum of resistance to heavy metals namely $\mathrm{Zn}, \mathrm{Cu}, \mathrm{Mn}, \mathrm{Cr}, \mathrm{Pb}, \mathrm{Ni}$ and $\mathrm{Cd}$ (Figure 6). Among the heavy metals, $\mathrm{Pb}$ removal by Achromobacter xylosoxidans was found to be maximum after $48 \mathrm{~h}$ incubation at $100 \mathrm{ppm}$ concentration. The important processes which may lead to metal removal might be binding of heavy metals to the cell surface or due to the intracellular uptake of the metals [18].

\section{Infrared spectrum analysis}

Infrared spectroscopy is the study of infrared light with matter [12]. The fundamental measurement obtained in infrared FTIR spectroscopy is in the infrared spectrum, which is a plot of measured infrared intensity versus wavelength (or wave number in $\mathrm{cm}^{-1}$ ). FTIR spectroscopy is sensitive to the presence of chemical functional groups

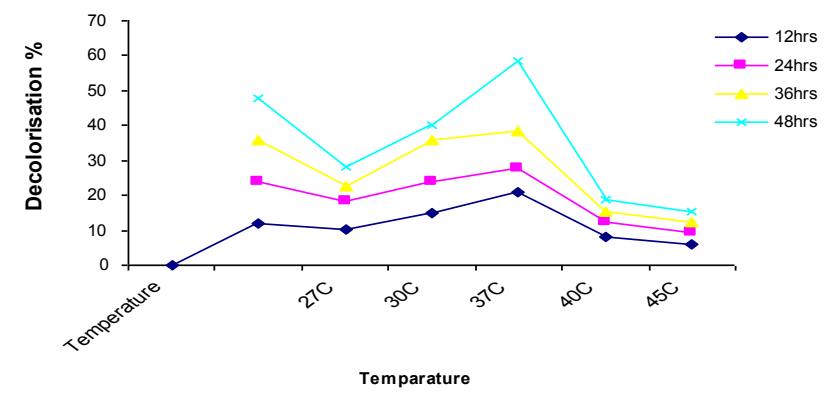

Figure 3: The decolorization rate of Achromobacter xylosoxidans at different temperature at different time interval.

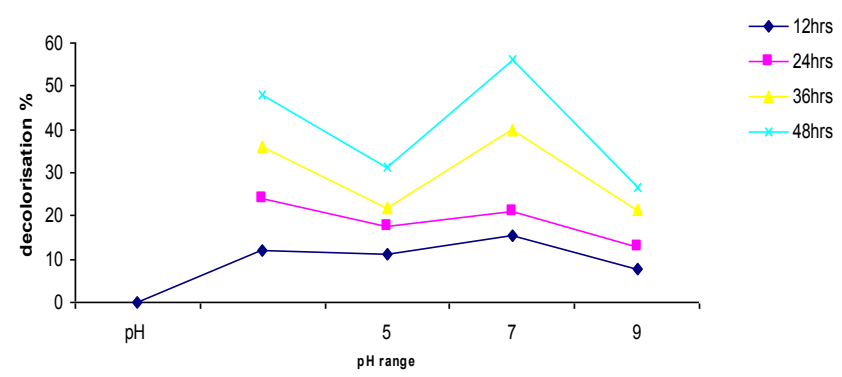

Figure 4: The decolorization rate of Achromobacter xylosoxidans at different $\mathrm{pH}$ with different time interval.

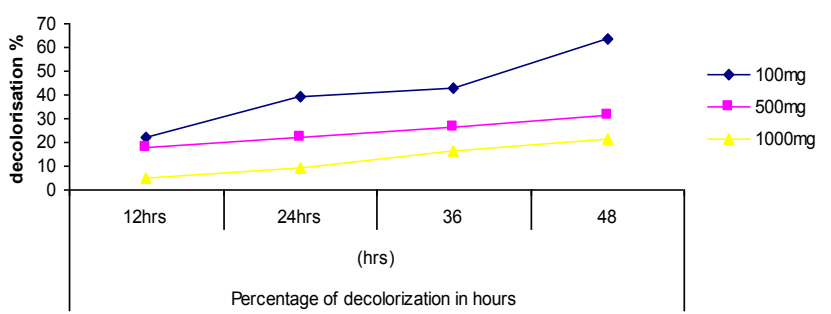

Figure 5: The decolorization rate of Achromobacter xylosoxidans at different concentration of dye at different time interval.

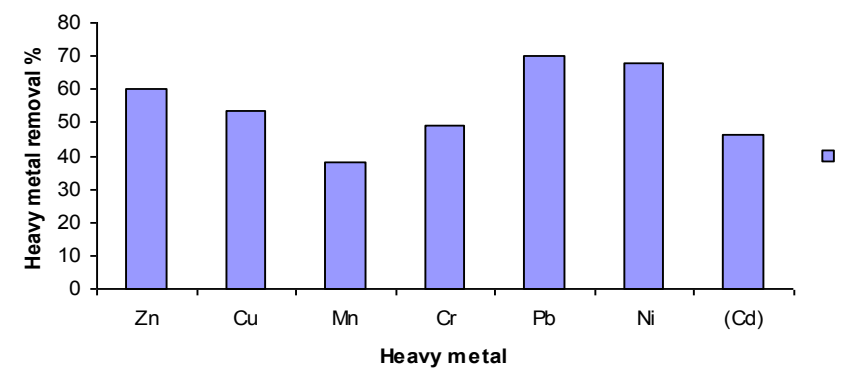

Figure 6: Heavy metal removal by of Achromobacter xylosoxidans at $37^{\circ} \mathrm{C}$ at $100 \mathrm{mg} / \mathrm{l}$ of dye.

in the prepared sample. A structural group is a structural fragment within a molecule.

The FTIR spectrum of the dye Turquoise blue dye and degraded products are depicted in (Figure $7 \mathrm{a}$ and $7 \mathrm{~b}$ ); with major absorption bands. The FTIR spectrum of $48 \mathrm{~h}$ extracted metabolites showed significant changes in position of peaks when compared to the control. In $48 \mathrm{~h}$, extracted metabolites recorded peak at $3435 \mathrm{~cm}^{-1}$, and 2913 $\mathrm{cm}^{-1}$ and these points are corresponding to -NH-(Stretching) in amine group whereas peak at $1586 \mathrm{~cm}^{-1} \mathrm{~N}-\mathrm{H}$ (bending) and $1363 \mathrm{~cm}^{-1}$ these points are corresponding to $\mathrm{C}-\mathrm{O}$ (stretching ). The stretching vibrations between $\mathrm{C}-\mathrm{N}$ showed bonds at $1171 \mathrm{~cm}^{-1}$. The major peaks appeared in control is sifted and the intensity of the peaks is decreased.

\section{Conclusion}

This study revealed the molecular identity of bacterial strain Achromobacter xylosoxidans GRIRKNM11 an isolate from dye polluted site and its potentials in bioremediation of textile dyes at optimum temperature, $\mathrm{pH}$ and dye concentration. This study also recorded the efficiency of the above strain in the removal of heavy metals. 
Citation: Manikandan N, Kuzhali SS, Kumuthakalavalli R (2012) Biodegradation of Textile Dye by Using Achromobacter xylosoxidans GRIRKNM11 Isolated from Dye Polluted Site. J Environ Anal Toxicol 2:160. doi:10.4172/2161-0525.1000160

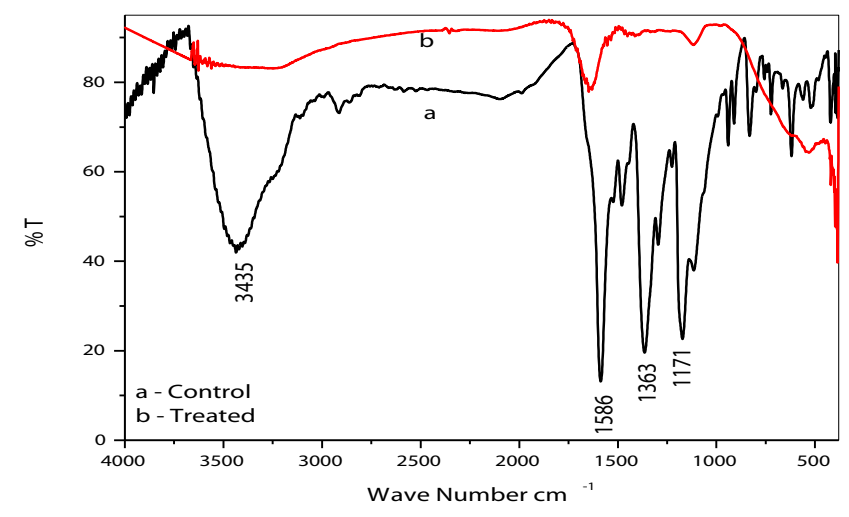

Figure 7: a, b FTIR analysis of treated and untreated dye by of Achromobacter xylosoxidans at $48 \mathrm{~h}$ incubation.

\section{Acknowledgements}

The authors are thankful to authorities of The Gandhigram Rural Institute(Deemed University ), Dindigul, Tamil Nadu (India) for providing research facilities and also thankful to the UGC (University Grants Commission, New Delhi) for providing financial assistance to the authors.

\section{References}

1. Jin XC, Liu GQ, Xu ZH, Tao WY (2007) Decolorization of a dye industry effluent by Aspergillus fumigatus XC6. Appl Microbiol Biotechnol 74: 239-243.

2. Garcia-Montan OJ, Domenech X, Garcia-Hortal JA, Torrades F, Peral J (2007) The testing of several biological and chemical coupled treatments for cibacorn red FN-R azo dye removal. J Hazard Mater 154: 484-490.

3. Wang W (1991) Toxicity assessment of pretreated industrial effluent using higher plant. Res J Water Pollut Control Fed 62: 853-860.

4. Chung KT (1983) The significance of azo-reduction in the mutagenesis and carcinogenesis of azo dyes. Mutat Res 114: 2690-281.

5. Robinson T, McMullan G, Marchant R, Nigam P (2001a) Remediation of dyes in textile effluent: a critical review on current treatment technologies with a proposed alternative. Bioresour Technol 77: 247-255.
6. Eloussaief M, Sdiri A, Benzina M (2012) Modelling the adsorption of mercury onto natural and aluminium pillared clays. Environ Sci Pollut Res Int.

7. Asad S, Amoozegar MA, Pourbabaee AA, Sarbolouki MN, Dastgheib M (2007) Decolorization of textile azo dyes by newly isolated halophilic and halotolerant bacteria. Bioresour Technol 98: 2082-2088.

8. Grekova-Vasileva M, Popova I, Vassileva D, Topalova Y (2009) Isolation and characterization of microbial strain Azo29 capable of Azo dye colorisation. Biotechnol \& Biotechnol.

9. Pallavi C, Harsha I, Sandhya M (2010) Biodegradation and decolorisation of dye by mix consortia of bacteria and study of toxicity on Phaseolus mungo and Triticum aestivum. Asiatic J Biotech Res 1: 45-56.

10. Tripathi A, Srivastava SK (2011) Ecofriendly Treatment of Azo Dyes: Biodecolorization using Bacterial Strains. International Journal of Bioscience, Biochemistry and Bioinformatics 1.

11. APHA (2002) Standard Methods for the Examination of Water and Wastewater 20edn. Amer Public Health Assn, Washington, DC, USA.

12. Francison E, Zille A, Dias Guimaro Fabio, Ragagnin de Menezes Cristiano, Durrant Lucia Regina, et al. (2009) Biodegradation of textile azo dyes by a facultative Staphylococcus arlettae strain VN-11 using a sequential microaerophilic/aerobic process. International Biodeterioration and Biodegradation 63: 280-288.

13. Liu S, Suffita JM (1993) Ecology and evolution of microbial populations fo bioremediation. Trends Biotechnol 11: 344-352.

14. Stolz A (2001) Basic and applied aspect in the microbial degradation of azo dyes. Appl Microbiol Biotechnol 56: 69-80.

15. Kolekar YM, Pawar SP, Gawai, KR, Lokhande PD, Shouche YS, et al. (2008) Decolorization and degradation of Disperse Blue 79 and Acid Orange 10 by Bacillus fusiformis KMK5 isolated from the textile dye contaminated soil. Bioresour Technol 99: 8999-9003.

16. Pearce CL, Lloyd JR, Guthrie JT (2003) The removal of colour from textile waste water using whole bacterial cells: a review. Dyes and pigments 58:179196

17. Kalme SD, Parshetti GK, Jadhav SU, Govindwar SP (2006) Biodegradation of benzidine based dye Direct blue-6 by Pseudomonas demolyticum NCIM2112. Bioresour Technol 98: 1405-1410.

18. Strandberg GW, Arnold Jr WD (1988) Microbial accumulation of neptunium. J Indus Microbial 3: 329-331. 